\title{
DIAGNOSIS DAN PENGENDALIAN PENYAKIT INFEKSIUS PADA INDUK KUDA LAUT, Hippocampus kuda DI HATCHERY
}

\section{DISEASES INFECTION AND CONTROL MEASUREMENT ON SEAHORSE, Hippocampus kuda BROODSTOCK IN HATCHERY}

\author{
Des Roza* \\ Balai Besar Riset Budidaya Laut dan Penyuluhan Perikanan Gondol, Bali \\ *E-mail: desrozaboer14@gmail.com
}

\begin{abstract}
Seed production of seahorse, Hippocampus kuda from hatchery has been developed in North Bali. The purpose of this research to diagnose and control the causative agent of infectious disease on seahorse broodstock. However, high mortality of the seahorse broodstock occured during rearing period in the hatchery which caused by diseases infection. This experiment was done to diagnose and control measurement the causative agent of the seahorse diseases found in the hatchery. The results showed that MIC test using 1 ppm nifurpirinol 10\% and 2.5 ppm vetstrep was effective to inhibit the growth of Vibrio alginolyticus. Bath method in mixed solution of $0.5 \mathrm{ppm}$ copper sulfate and 20 ppm formalin was effective for Cryptocaryon irritans infection, while bath solution of 5 ppm acriflavin neutral and 20 ppm had killed Trichodina sp. Based on result of showed seahorse broodstock infected by bacterium fit to $\underline{V}$. alginolyticus characteristics and parasitic protozoan Cilliates, $\underline{C}$. irritans and Trichodina sp.
\end{abstract}

Keywords : bacterium, control measurement, diseases, protozoa, seahorse

\begin{abstract}
ABSTRAK
Produksi benih kuda laut, Hippocampus kuda di hatchery telah berkembang di Bali Utara. Tujuan penelitian ini untuk mendiagnosis dan pengendalian penyakit infeksius pada induk kuda laut di hatchery. Tetapi masalah yang dihadapi adalah tingginya tingkat kematian induk selama pemeliharaan di hatchery, yang diduga akibat infeksi penyakit. Penelitian ini dilakukan untuk mendiagnosis agen penyakit melalui serangkaian observasi, isolasi, dan identifikasi serta melakukan pengendalian penyakit. Hasil menunjukkan bahwa dari uji MIC memperlihatkan bahwa pertumbuhan bakteri $V$. alginolyticus dapat dihambat dengan larutan campuran $1 \mathrm{ppm}$ nifurpirinol $10 \%$ dan $2,5 \mathrm{ppm}$ vetstrep. Sedangkan penggunaan copper sulfat $0,5 \mathrm{ppm}$ dan formalin $20 \mathrm{ppm}$ mampu mematikan C. irritans, sementara itu acriflavin netral $5 \mathrm{ppm}$ dan formalin $20 \mathrm{ppm}$ efektif membunuh Trichodina sp. Berdasarkan hasil penelitian dapat disimpulkan dari induk kuda laut telah diperoleh satu isolat bakteri Vibrio alginolyticus dan duajenis protozoa Cilliata parasitic, yaitu Cryptocaryon irritans dan Trichodina sp.
\end{abstract}

Kata kunci : bakteri, kuda laut, pengendalian, penyakit, protozoa

\section{PENDAHULUAN}

Daerah Bali Utara telah dikembangkan budidaya kuda laut terutama Hippocampus kuda di hatchery. Awalnya usaha ini hanya sebagai alternatif pada saat harga benih kerapu dan nener bandeng anjlok. Tetapi setelah berjalan, beberapa pengusaha justru menjadikan usaha ini sebagai komoditas utama karena harga kuda laut ini sangat menjanjikan. Sebagaimana diketahui bahwa kuda laut ini selain diminati sebagai ikan hias akuarium juga banyak dicari sebagai bahan baku obat-obatan tradisional.

Kuda laut merupakan ikan hias akuarium yang sangat unik dengan daya tarik yang sangat mempesona, ini terlihat dari posisi tubuhnya yang tegak disaat berenang. Menurut Koldewey dan Smith (2010) 
keunikan lainnya adalah dalam proses reproduksinya, yaitu hewan jantan yang hamil dan mengerami telur sampai menetas. Sejak ribuan tahun silam kuda laut banyak digunakan sebagai bahan baku obat-obatan tradisional Cina "Traditional Chinese Medicine" (Hansen dan Cummins, 2002). Kuda laut berkhasiat untuk mengobati berbagai macam penyakit antara lain disfungsi jantung, ginjal dan hati, memperlancar peredaran darah, disfungsi vitalitas seksual, memperkuat rahim, mencegah kanker payudara, sakit kulit, gangguan pencernaan, pernapasan dan fungsi otak, anti aging serta masih banyak lagi. Hal ini yang menjadikan kuda laut bak primadona baik di pasar lokal maupun ekspor. Salah satu spesies kuda laut yang banyak diminati adalah $H$. kuda atau dikenal juga dengan tangkur kuda. Syafiuddin et al. (2008) melaporkan sebagai ikan hias harga seekor kuda laut berkisar antara Rp. 30.000-50.000, sedangkan untuk bahan obat-obatan kuda laut kering harganya Rp. 3.000.000-5.000.000/kg bahkan di Hongkong dan Cina harganya mencapai US \$ $1.000-1.500 / \mathrm{kg}$. Akibat tingginya permintaan pasar akan kuda laut kering, menyebabkan terjadinya eksploitasi yang berlebihan dan tanpa kendali, sehingga berdampak terhadap populasi kuda laut di alam terancam punah "vurnarable" (Asmanelli dan Ikhsan, 2000; Sadili, 2005).

Tahun 2004 dikeluarkan keputusan bahwa kuda laut termasuk ke dalam Appendix II CITES, dimana ekspor dan impor hewan ini menurut Mira dan Yulianto (2007) harus mempunyai izin (certificate of origin). Pawar et al. (2011) mengatakan kuda laut hidup pada zona litoral atau perairan lepas pantai, dimana penetrasi cahaya matahari dapat masuk ke dasar perairan. Sedangkan penyebarannya meliputi Samudera Hindia dan Samudera Pasifik sampai ke kepulauan Hawai dan Jepang berdasarkan hasil penelitian Faleiro et al. (2008) dan Raj et al. (2010). Di alam musim memijah kuda laut, $H$. kuda hanya berlangsung beberapa bulan dalam setahun dan puncaknya pada Oktober-Pebruari. Family Syngnathidae termasuk kuda laut mempunyai musim kawin sepanjang tahun. Vincent and Clifton (2001) menyatakan pemijahan terjadi biasanya di pagi, siang dan sore hari karena hewan ini termasuk "diurnal" atau aktif pada siang hari. Umumnya seekor induk betina Hippocampus spp. menghasilkan 100-200 butir telur, tetapi seekor induk betina $H$. kuda dengan panjang tubuh 10-14 cm bisa menghasilkan 300-600 butir telur (Ari et al., 2005; Mira dan Yulianto, 2007). Setelah 10-15 hari kuda laut ini dapat memijah kembali, karena hanya butuh waktu 10-12 hari untuk pematangan gonadnya (Vincent and Clifton, 2001; Asmanelli dan Ikhsan, 2000).

Berdasarkan hal tersebut telah banyak dilakukan upaya budidaya kuda laut ini, salah satunya dengan usaha pembenihannya di hatchery. Beberapa tahun belakangan ini di hatchery sering mengalami kendala yaitu terjadinya kematian induk secara massal. Salah satu penyebabnya diduga akibat adanya infeksi penyakit, untuk itu dilakukan monitoring dan observasi terhadap induk kuda laut yang dipelihara di hatchery di daerah Bali Utara, diharapkan dengan mengetahui agen penyebab serta teknik penanggulangannya dapat meminimalisir tingkat kematian sehingga produksi kuda laut meningkat. Penelitian ini bertujuan untuk mendiagnosis dan pengendalian penyakit infeksius pada induk kuda laut di hatchery.

\section{METODE PENELITIAN}

\subsection{Waktu dan Lokasi Penelitian}

Penelitian ini dilakukan di Laboratorium Patologi Balai Besar Riset Budidaya Laut dan Penyuluhan Perikanan (BBRBLPP) Gondol, Gerokgak, Buleleng, Bali dari bulan September 2016 sampai Februari 2017.

\subsection{Hewan Uji}

Hewan uji yang digunakan dalam penelitian ini adalah induk kuda laut, 
Hippocampus kuda milik hatchery swasta di Sanggalangit, Gerokgak, Buleleng, Bali (Gambar 1 dan 2). Terhadap hatchery yang mengalami kasus kematian dilakukan pengambilan sampel induk kuda laut masingmasing sebanyak 20 ekor pada bulan September dan November 2016 serta Januari 2017 dengan panjang berkisar antara 11-15 $\mathrm{cm}$ dan berat tubuh 10-17 g. Induk-induk kuda laut tersebut dibawa ke Laboratorium Patologi Balai Besar Riset Budidaya Laut dan Penyuluhan Perikanan (BBRBLPP) Gondol, Gerokgak, Buleleng, Bali dalam keadaan hidup dengan dimasukan ke dalam kantong plastik dan ditambahkan oksigen untuk diobservasi. Pengamatan induk dilakukan secara visual untuk mengetahui gejala klinis dan secara mikroskopis untuk mengetahui adanya organisme penempel penyebab infeksi, baik bakteri maupun parasit. Kemudian dilanjutkan dengan serangkaian proses isolasi terutama untuk bakteri.

\subsection{Isolasi Bakteri}

Isolasi bakteri dari sampel induk kuda laut dilakukan menggunakan empat jenis media agar, antara lain TSA (Trycticase Soy Agar) media ini merupakan media yang umum untuk tumbuh semua jenis bakteri, TCBSA (Thiosulphate Citrate Bile Sucrose Agar) adalah agar selektif untuk Vibrio. Sebagian kecil potongan tubuh kuda laut yang diduga terinfeksi bakteri masingmasing diinokulasikan pada ke 2 media tersebut, kemudian diinkubasi pada inkubator dengan suhu $27^{\circ} \mathrm{C}$ selama 8-12 jam. Terhadap koloni bakteri yang tumbuh dominan dilakukan purifikasi dengan menggunakan media MA (Marine Agar) dan isolat bakteri yang telah dipurifikasi diuji karakteristik morfologi seperti penelitian Holt et al. (2000) dan Roza (2017).

\subsection{Pengamatan Parasit}

Pengamatan parasit dilakukan dengan mengamati preparat segar lendir permukaan tubuh dan potongan organ tubuh induk kuda laut termasuk organ dalam antara lain ginjal, hepar dan lambung. Lendir dan bagian organ tubuh tersebut diletakkan pada gelas objek dan ditutup dengan gelas penutup, kemudian diamati di bawah mikroskop pada pembesaran $5 \times 10$ dan $10 \times 20$. Parasit yang ditemukan kemudian diidentifikasi mengikuti Vincent dan Clifton (2001) dan Sanaye et al. (2013).

\subsection{Pencegahan dan Penanggulangan Penyakit \\ Pencegahan dan penanggulangan} infeksi bakteri dan protozoa dilakukan dengan uji MIC secara in vitro (Minimum Inhibitory Concentration) menggunakan 2 jenis antibiotik dan 2 jenis anti parasit berdasarkan Roza et al. (2010) dan Roza (2011). Ke dalam cawan petri berisi $20 \mathrm{~mL}$ air laut steril yang sudah dicampur dengan masing-masing konsentrasi antibiotik yaitu 0 ; 0,$1 ; 0,25 ; 0,5 ; 1 ; 2,5 ; 5 ; 10 ; 25 ; 50$ dan 100 ppm diinokulasikan $V$. alginolyticus, kemudian inkubasi pada $25^{\circ} \mathrm{C}$ selama 24 jam. Setelah masa inkubasi diamati pertumbuhan bakteri tersebut, lalu dilakukan reisolasi pada media TSA untuk konfirmasi pertumbuhan bakteri. Konsentrasi antibiotik dan antiparasit diaplikasikan langsung pada bak induk kuda laut dengan cara perendaman selama satu jam. Konsentrasi dikatakan efektif apabila dapat menghambat atau membunuh pertumbuhan bakteri atau parasit.

\section{HASIL DAN PEMBAHASAN}

\subsection{Hasil}

Selama periode bulan September 2016 sampai Februari 2017 terjadi kematian massal induk kuda laut, Hippocampus kuda di hatchery milik swasta di wilayah Bali Utara. Hal ini sudah sering terjadi sebelumnya tapi tidak dilaporkan. Secara visual induk kuda laut, $H$. kuda yang mati terlihat warna tubuhnya mengalami perubahan menjadi pucat agak keputihan dan juga ditemukan adanya bintik-bintik putih. Gejala klinis yang terlihat sebelum terjadinya 
kematian, beberapa ekor induk kuda laut diam di dasar bak dan tidak lincah berenang seperti biasanya, kadang-kadang bergerak tidak terkontrol, bahkan ada yang menggesekkan badannya ke dinding bak. Beberapa hari setelah itu induk kuda laut ditemukan mati.

\subsubsection{Morfologi Kuda Laut H. kuda}

Secara morfologi tubuh kuda laut, $H$. kuda tergolong unik karena kepalanya berbentuk segitiga mirip kepala kuda, mulut atau moncong panjang dan membentuk sudut $90^{\circ}$ dengan badannya. Menurut Lin et al. (2006) dan Lourie et al. (2001) bagian tubuhnya tidak bersisik tetapi ditutupi oleh segmen tulang yang menyerupai perisai, mempunyai satu sirip punggung (dorsal fin), sepasang sirip dada (pectoral fin) dan satu sirip anus (anal fin). Kuda laut sangat lambat ketika berenang karena posisi tubuhnya vertikal sehingga tekanan air pada tubuhnya menjadi besar, yang membuat gerakannya lambat. Sadili (2015) melaporkan di saat kuda laut berenang lambat, maka dengan kecepatan penuh sirip-siripnya bergetar selaju 35 getaran/detik, tetapi menurut Lourie et al. (2001); Lin et al. (2008; 2009b) dan Sadili (2015) kemampuan kuda laut merubah warna tubuhnya atau mimikri merupakan suatu upaya berkamuflase dalam mengelabui musuh, predator maupun mangsanya. Kuda laut memiliki baju zirah terbaik, bentuk tulangnya cenderung kotak dan memiliki kerangka tulang yang cukup kompleks.

Hewan ini sangat rakus karena tidak memiliki perut untuk menampung makanan, makanan hanya lewat, itulah sebabnya mereka harus makan terus menerus sepanjang hari atau mereka tidak akan bertahan hidup (Lourie et al., 1993; Asmanelli dan Ikhsan, 2000). Kuda laut termasuk karnivora karena memakan zooplankton dan udang kecil, moncongnya yang panjang berfungsi untuk menyedot mangsa. Selain itu kuda laut hidup dengan satu pasangan (monogami), sangat setia dengan pasangannya dan mereka ber- hubungan hampir sepanjang tahun berdasarkan penelitian Wooten (2005) dan Lin et al. (2009a). Kuda laut kering yang dijadikan obat dalam bentuk tepung berwarna kuning dan putih, rasanya manis, hangat dan sedikit asin yang berkhasiat untuk kesehatan karena mengandung asam stearat, protease, $y$ caroten, astacene, melanin, cholimesterase, sodium klorida, magnesium dan sulfat (Sanaye et al., 2013).

\subsubsection{Bakteri}

Telah diisolasi 1 isolat bakteri dengan karakteristik antara lain gram negatif, oksidase dan katalase positif, fermentatif, motil dan tidak dapat mensintesa sukrosa sehingga koloni pada TCBSA berwarna kuning dan menyebar (swarming) pada TSA. Isolat ini diisolasi dari organ eksternal, sedangkan dari organ internal tidak ditemukan adanya bakteri.

Berdasarkan karakteristik tersebut yang sesuai dengan hasil penelitian Holt et al. (2000) dan Roza (2017), disimpulkan isolat termasuk genus Vibrio dan diidentifikasi sebagai $V$. alginolyticus. Karakteristik isolat bakteri disajikan pada Tabel 1.

\section{Tabel 1. Karakteristik isolat Vibrio alginolyticus yang diisolasi dari induk kuda laut, $H$. kuda.}

\begin{tabular}{lc}
\hline \multicolumn{1}{c}{ Karakteristik } & $\begin{array}{c}\text { Isolat Vibrio } \\
\text { alginolyticus }\end{array}$ \\
\hline Gram & $-^{1}$ \\
Oksidase & $+^{2}$ \\
Katalase & + \\
Motil & + \\
O-F & $\mathrm{F}^{3}$ \\
Koloni pada & $\mathrm{Y}^{4}$ \\
TCBSA & \\
$\begin{array}{l}\text { Koloni } \\
\text { menyebar pada }\end{array}$ & + \\
TSA & \\
\hline Keterangan ${ }^{1=}$ negatif, ${ }^{2}=$ positif, ${ }^{3}=$ \\
fermentatif, dan ${ }^{4}=$ kuning.
\end{tabular}


Hasil pengamatan Roza (2017) memperlihatkan bahwa bakteri Vibrio alginolyticus merupakan bakteri gram negatif yang berbentuk batang bengkok, oksidase dan katalase positif, memfermentasi glukosa tanpa menghasilkan gas dan mempunyai flagel polar.

\subsubsection{Parasit}

Pengamatan terhadap lendir yang diambil dari permukaan tubuh dan insang induk kuda laut terlihat banyak ektoparasit protozoa Ciliata, Cryptocaryon irritans dan Trichodina sp., sedangkan dari jaringan otot dan internal organ tidak ditemukan adanya endoparasit C. irritans. Bulan September prevalensi $C$. irritans menempati urutan terbesar yaitu $60 \%$, November hanya $40 \%$ dan Januari sebesar 55\%. Sedangkan prevalensi Trichodina sp. terlihat lebih rendah hanya $35 \%$ di bulan September, November $45 \%$ dan Januari hanya 30\%.

Infeksi Cryptocaryon disebut juga Cryptocariosis atau penyakit (white spot) karena menyebabkan adanya bercak putih pada operkulum (tutup insang) dan permukaan tubuh inang. Roza et al. (2010) melaporkan bahwa protozoa ciliata ini merupakan ektoparasit yang umum ditemukan pada ikan budidaya.

Kondisi infeksi berat protozoa bisa menutupi seluruh tubuh, sehingga produksi lendir akan meningkat dan berpeluang terjadinya infeksi sekunder yang berakibat pada kematian. Protozoa ini akan menyerang apabila kondisi ikan lemah.

Menurut Vincent dan Clifton (2001); Roza et al. (2010) dan Zafran (2016) gejala klinis ikan yang terserang parasit ini terlihat nafsu makan menurun, bergerak lamban, berenang di permukaan bahkan berdiam di dasar bak tanpa bergerak, warna tubuh keputih-putihan dan anoreksia.

Ikan yang terinfeksi pada bagian mata akan menyebabkan terjadinya radang pada mata dan kalau infeksi ini tidak cepat ditangani, akan memberi peluang bagi infeksi sekunder bakteri. Shin et al. (2011) dan Sanaye et al. (2013) menemukan insang pucat dan kadang-kadang lamelanya rusak sehingga proses respirasi terganggu.

Umumnya ikan yang terinfeksi $C$. irritans akan mengalami kematian dalam 2-3 hari, selain itu juga ditemukan induk kuda laut terinfeksi Trichodiniosis penyebabnya adalah protozoa ciliata, Trichodina sp. bentuk tubuhnya datar seperti cawan dengan diameter $100 \mu \mathrm{m}$, disekeliling tubuhnya terdapat bulu getar atau cilia (marginal dan lateral), bentuk susunannya khas mirip dengan susunan gigi. Menurut Lom (2005) pada tubuh bagian bawah terdapat lingkaran pelekat (adhesive disk) untuk melekatkan dirinya ke tubuh inang.

Umumnya parasit ini hidup menempel pada insang dan kulit dengan pergerakan memutar dimana hal ini dapat merusak jaringan inang. Infeksi Trichodina sp. ini bisa ditemukan pada budidaya ikan air tawar maupun laut.

Bila dibandingkan dengan C. irritans, Trichodina sp. tidak begitu patogen, tetapi hasil penelitian Castrillo et al. (2005) pada tingkat infeksi parah, baik pada insang maupun permukaan tubuh akan memicu produksi lendir yang berlebihan, sehingga menimbulkan peradangan.

Hasil penelitian Zafran et al. (1998) dan Cruz-Lacierda (2001) menunjukkan bahwa Trichodina sp. pada infeksi dini gejalanya tidak terlihat, hanya terlihat kuda laut banyak diam di dasar bak, sedangkan infeksi berat ditandai dengan meningkatnya produksi lendir, terjadinya iritasi akibat alat pengait (hook) dari parasit tersebut dan anoreksia (Shin et al. 2011) dan Sanaye et al. (2013).

Ikan yang terinfeksi umumnya terlihat menggesekkan badannya pada dinding atau dasar bak. Trichodina sp. tergolong parasit yang kosmopolit karena ditemukan diseluruh perairan dan menginfeksi ikan air tawar dan laut. 
Tabel 2. Prevalensi ektoparasit pada induk Kuda Laut $H$. kuda.

\begin{tabular}{cccc}
\hline \multirow{2}{*}{ Parasit } & \multicolumn{3}{c}{ Prevalensi (\%) } \\
\cline { 2 - 4 } & September 2016 & November 2016 & Januari 2017 \\
\hline Cryptocaryon irritans & 60 & 40 & 55 \\
Trichodina sp. & 35 & 45 & 30 \\
\hline
\end{tabular}

3.2. Pencegahan dan Penanggulangan Infeksi Bakteri dan Parasit

Pencegahan infeksi bakteri dan parasit dapat dilakukan dengan sterilisasi air dan peralatan yang akan digunakan, treatment/desinfeksi dan karantina induk sebelum dipelihara di hatchery, menjaga kualitas air pemeliharaan yang baik, menghindari stres akibat padat tebar yang tinggi dan handling yang kurang baik serta pemberian pakan yang berkualitas baik. Raj et al.(2010) menyatakan penggunaan obat dengan dosis tertentu dapat mengganggu respons imun ikan, selain dari sensitivitas masing-masing patogen berbeda terhadap jenis obat.

\subsubsection{MIC test atau Konsentrasi Hambat terendah nifurpirinol $10 \%$ dan vetstrep terhadap bakteri $V$. alginolyticus}

Uji MIC nifurpirinol $10 \%$ dan vetstrep memperlihatkan hasil yang berbeda terhadap $V$. Alginolyticus. Pada perlakuan nifurpirinol $10 \%$ dengan konsentrasi $0 ; 0,1$; 0,$25 ; 0,5$ ppm bakteri masih tumbuh dengan baik, sedangkan pada konsentrasi $1 ; 2,5 ; 5$; 10; 25; 50 dan 100 sama sekali tidak terlihat pertumbuhannya. Tetapi vetstrep dengan konsentrasi $0 ; 0,1 ; 0,25 ; 0,5$ dan 1 ppm belum mampu menekan pertumbuhan $V$. alginolyticus dan baru bisa membunuhnya pada konsentrasi 2,5; 5; 10;25; 50 dan 100 ppm. Hal ini ditandai dengan jernihnya warna media, selain itu dari reisolasi pada media TSA juga tidak ada pertumbuhan $V$. alginolyticus. Hasil uji MIC disajikan pada Tabel 3.

Berdasarkan hasil uji MIC diatas, konsentrasi $1 \mathrm{ppm}$ nifurpirinol10\% dan 2,5 ppm vetstrep efektif untuk menanggulangi infeksi $V$. alginolyticuspada induk kuda laut.

Hasil penelitian Roza et al. (2001) menunjukkan bahwa nifurpirinol $10 \%$ dan vetstrep termasuk jenis antibiotic yang mempunyai spektrum luas karena mampu membunuh bakteri gram positif maupun gram negatif. Selain itu Roza (2017)

Tabel 3. MIC nifurpirinol 10\% dan vetstrep terhadap pertumbuhan $V$. Alginolyticus.

\begin{tabular}{cccccc}
\hline \multirow{2}{*}{ Konsentrasi (ppm) } & \multicolumn{3}{c}{ Antibiotik } & \multicolumn{3}{c}{ Reisolasi } \\
\cline { 2 - 6 } & Nifurpirinol $10 \%$ & Vetstrep & Nifurpirinol 10\% & Vetstrep \\
\hline 0,00 & $++^{+}$ & ++ & + & + \\
0,10 & ++ & ++ & + & + \\
0,25 & ++ & ++ & + & + \\
0,50 & $+^{2}$ & + & - & + \\
1,00 & - & + & - & + \\
2,50 & - & - & - & - \\
5,00 & - & - & - & - \\
10,00 & - & - & - & - \\
25,00 & - & - & - & - \\
50,00 & - & - & - & - \\
100,00 & - & - & &
\end{tabular}

Keterangan: ${ }^{1}=$ tumbuh optimal, ${ }^{2}=$ tumbuh, dan ${ }^{3}=$ tidak tumbuh. 
melaporkan bahwa sensitivitas bakteri terhadap antibiotik juga tergantung pada genus, spesies maupun strainnya, seperti $V$. alginolyticus yang menginfeksi ikan capungan Banggai, $P$. kauderni dapat dikendalikan dengan 2 ppm nifurpirinol dan 5 ppm vetstrep. Berdasarkan data ini diketahui bahwa isolat $V$. alginolyticus yang menginfeksi induk kuda laut ini lebih sensitif dibandingkan dengan isolat $V$. alginolyticus yang menginfeksi ikan capungan Banggai.

\subsubsection{MIC Copper Sulfate, acriflavin dan Formalin Terhadap Protozoa Ciliata, $C$. irritans dan Trichodina}

sp.

Hasil uji MIC antiparasit copper sulfate dan formalin terhadap protozoa Ciliata, C. irritans dapat dilihat pada Tabel 4 dan hasil uji dengan acriflavin netral dan formalin dalam menanggulangi infeksi protozoa, Trichodina sp. (Tabel 5).

Tabel 4. MIC test copper sulfate dan formalin terhadap protozoa Ciliata, C. irritans.

\begin{tabular}{ccc}
\hline \multirow{2}{*}{$\begin{array}{c}\text { Konsentrasi } \\
(\text { ppm })\end{array}$} & \multicolumn{2}{c}{ Antiparasit } \\
\cline { 2 - 3 } & $\begin{array}{c}\text { Copper } \\
\text { sulfate }\end{array}$ & Formalin \\
\hline 0,00 & +1 & + \\
0,10 & + & + \\
0,25 & + & + \\
0,50 & - & + \\
1,00 & - & + \\
2,50 & - & + \\
5,00 & - & + \\
10,00 & - & + \\
15,00 & - & + \\
20,00 & - & - \\
25,00 & - & - \\
50,00 & - & - \\
100,00 & - & - \\
\hline
\end{tabular}

Keterangan: ${ }^{1}=$ parasit bertahan hidup dan ${ }^{2}$ $=$ parasit mati.

Perendaman dalam larutan copper sulfate dan formalin dengan konsentrasi masing-masing 0,5 dan 20 ppm berdampak mematikan bagi $C$. irritans, dan terbukti pada pengamatan ulang terhadap lendir permukaan tubuh, insang dan mata setelah perendaman tidak ditemukan lagi. Menurut Zafran (2016) bagian tubuh tersebut merupakan bagian yang disukai protozoa ini untuk hidup menempel. Infeksi $C$. irritans pada tingkat parah ditandai dengan adanya bintik-bintik putih pada tubuh inang. Ektoparasit ini tergolong sangat berbahaya pada marikultur karena hasil penelitian Roza et al. (2010) kalau terlambat ditangani infeksinya akan menyebar dengan cepat, sehingga ikan yang sehatpun akan terinfeksi dan dapat berujung pada kematian massal hanya dalam 2-3 hari. Sedangkan Vincent dan Clifton (2001) mengatakan Cryptocaryon mengganggu proses respirasi karena memakan lamela insang.

Tabel 5. MIC test acriflavin netral dan formalin terhadap protozoa Ciliata, Trichodina sp.

\begin{tabular}{ccc}
\hline \multirow{2}{*}{$\begin{array}{c}\text { Konsentrasi } \\
(\mathrm{ppm})\end{array}$} & \multicolumn{2}{c}{ Antiparasit } \\
\cline { 2 - 3 } & $\begin{array}{c}\text { Acriflavin } \\
\text { netral }\end{array}$ & Formalin \\
\hline 0,00 & +1 & + \\
0,10 & + & + \\
0,25 & + & + \\
0,50 & + & + \\
1,00 & + & + \\
2,50 & + & + \\
5,00 & -2 & + \\
10,00 & - & + \\
15,00 & - & - \\
20,00 & - & - \\
25,00 & - & - \\
50,00 & - & - \\
100,00 & - & - \\
\hline
\end{tabular}

Keterangan: ${ }^{1}=$ parasit bertahan hidup dan ${ }^{2}$ $=$ parasit mati

Berdasarkan Tabel 5, perendaman dalam larutan acriflavin netral $5 \mathrm{ppm}$ dan formalin 20 ppm efektif membunuh Trichodina sp., sementara pada konsentrasi 
yang lebih rendah parasit ini masih bertahan hidup. Pada prinsipnya infeksi parasit pada budidaya tidak hanya ditentukan oleh jenis dan jumlah parasit yang menyerang, tetapi dipengaruhi oleh kondisi lingkungan dan daya tahan tubuh ikan.

\subsection{Pembahasan}

$V$. alginolyticus merupakan bakteri yang umum ditemukan pada perairan laut dan estuaria, bakteri ini bersifat patogen oportunistik hal ini sesuai dengan pernyataan Balcazar et al. (2010); Johnny dan Roza (2014) dan Roza (2011; 2017), dimana akan patogen apabila ada faktor lain yang mendukung, misalnya kondisi kuda laut yang stress, kualitas air yang buruk, pakan berkualitas rendah, padat tebar yang terlalu tinggi, handling yang kasar, dan lain-lain. Keberadaan $V$. alginolyticus akan membahayakan apabila populasinya tinggi, dalam jumlah yang kecil dengan lingkungan budidaya yang optimal bakteri ini justru akan menguntungkan karena dapat membantu proses pencernaan (Roza dan Zafran, 1998; Roza et al., 1999). Bahkan Roza et al. (2001) menemukan bahwa $V$. alginolyticus pada kepadatan tertentu dapat berperan sebagai musuh alami dari $V$. harveyi. Sanaye et al. (2013) dan Adiputra et al. (2005) menyatakan bahwa bakteri yang menjadi ancaman pada budidaya kuda laut diantaranya adalah Vibrio, Photobacterium, Bacillus dan Pseudomonas, bahkan Alcaide et al. (2001) dan Raj et al. (2010) menyebutkan bahwa $V$. harveyi pada kepadatan $10^{4} \mathrm{CFU} / \mathrm{mL}$ sudah mematikan bagi kuda laut.

Bakteri $V$. alginolyticus termasuk fermenter sukrosa yang ditandai dengan koloninya berwarna kuning pada media TCBSA yang merupakan media selektif untuk Vibrio. Menurut Desrina et al. (2006) bahwa Vibrio yang bersifat enteropatogenik termasuk ke dalam fermenter sukrosa dengan ciri khas koloninya berwarna kuning, sedangkan bakteri nonfermenter koloninya berwarna hijau. Karakter lain dari $V$. alginolyticus yaitu koloninya swarming (menyebar) pada media padat, hal ini disebabkan karena bakteri ini mensintesa flagella lateral yang banyak. Pada marikultur kematian massal yang disebabkan oleh infeksi $V$. alginolyticus mencapai $90-100 \%$. Gejala klinis serangan bakteri ini terlihat dari menurunnya nafsu makan, bergerak lamban, keseimbangan terganggu (berputar-putar/ whirling), perubahan tingkah laku dan terjadinya luka borok. Menurut Yanuhar (2009) $V$. alginolyticus merupakan bakteri yang lebih virulen berdasarkan titer haemoglutinin. Patogenisitas bakteri ini tergantung pada peran dan fungsi dari protein reseptor dan protein adesi yang melibatkan peran reseptor spesifik pada permukaan sel.

Beberapa peneliti Roza et al. (2010) dan Zafran (2016) melaporkan bahwa $C$. irritans protozoa ciliata merupakan ektoparasit yang umum ditemukan pada ikan budidaya. Infeksi berat protozoa bisa menutupi seluruh tubuh, sehingga produksi lendir akan meningkat dan berpeluang terjadinya infeksi sekunder yang akhirnya berakibat pada kematian. Biasanya infeksi protozoa ini akan menyerang apabila kondisi ikan lemah. Gejala klinis, ikan yang terserang parasit ini menurut Roza et al. (2010) akan terlihat nafsu makan menurun, bergerak lamban, berenang di permukaan bahkan berdiam di dasar bak tanpa bergerak, warna tubuh keputih-putihan dan anoreksi. Ikan yang terinfeksi pada bagian mata akan menyebabkan terjadinya radang pada mata dan kalau infeksi ini tidak cepat ditangani, akan memberi peluang bagi infeksi sekunder bakteri. Bahkan Shin et al. (2011) dan Sanaye et al. (2013) menemukan insang pucat dan lamelanya rusak sehingga mengakibatkan proses respirasi terganggu. Umumnya ikan yang terinfeksi $C$. irritans akan mengalami kematian dalam 2-3 hari.

Parasit C. irritans ini dapat terlihat langsung di bawah sinar matahari tanpa bantuan mikroskop. Parasit ini mempunyai beberapa stadia dalam siklus hidupnya. Stadia parasit yang hidup menempel pada 
inang disebut "trophont" berbentuk bulat seperti buah pir dengan ukuran 0,3-0,5 mm, mempunyai cilia pada permukaan tubuhnya, hidup dan bergerak aktif dibawah kulit dan insang. Parasit dewasa atau "tomont" akan meninggalkan inang dan aktif berenang di air dan setelah beberapa jam kemudian tomont akan membentuk kista di dasar bak. Dalam waktu 6-9 hari kista akan menetas dan bisa menghasilkan 200 atau lebih parasit muda atau "theront" dengan ukuran $35 \mu \mathrm{m}$. Wooten (2005) melaporkan theront ini akan berenang aktif untuk mencari inang baru dan apabila dalam waktu 24 jam atau lebih theront tidak menemukan inang baru, maka ia akan mengalami kematian.

Penanggulangan sangat diperlukan pengamatan khusus untuk mengetahui stadianya karena belum ditemukan bahan kimia atau antiparasit yang efektif untuk membunuh pada stadia trophont maupun kista. Roza et al. (2010) menyatakan antiparasit hanya efektif untuk menanggulangi $C$. irritans pada stadia tomont dan theront. Terlihat copper sulfate $0,3 \mathrm{ppm}$ dan formalin 20 ppm efektif membunuh tomont dan theront. Selain itu perendaman induk kuda laut dalam air payau (10-15 ppt) juga dapat mematikan theront. Hal yang sangat penting diperhatikan dalam penanganan parasit adalah mempertahankan konsentrasi antiparasit pada dosis yang mematikan selama 57 hari. Pada kondisi ini parasit akan melepaskan diri dari inang dan dengan memindahkan induk kuda laut sesegera mungkin setelah ditreatmen ke dalam bak yang bersih dan bebas parasit, hal ini bertujuan untuk mencegah kemungkinan adanya kista yang tertinggal di dasar bak saat pengobatan.

Sebagaimana diketahui bahwa pertahanan pertama ikan terhadap infeksi penyakit berada dipermukaan kulit, yaitu lendir (mukus), jaringan epitalia dan insang. Lendir yang melapisi seluruh permukaan integumen termasuk kulit, insang dan perut. Beberapa peneliti diantaranya Roza et al. (2010) dan Zafran (2016) menemukan pada saat terjadi infeksi atau iritasi fisik dan kimiawi sekresi mukus akan meningkat. Lapisan mukus secara tetap dan teratur akan diperbarui, sehingga kotoran yang menempel ditubuhnya ikut dibersihkan. Mukus ikan mengandung lisosim, komplemen, antibodi (Ig M) dan protease yang berperan untuk mendegradasi dan mengeliminir patogen.

Mekanisme kerja antibiotik digolongkan 2 kelompok yaitu bactericidal dan bacteriostatic. Bactericidal cara kerjanya dengan merusak satu persatu bakteri yang menginfeksi dengan menghancurkan dinding sel bakteri sehingga bakteri tersebut mati. Sedangkan bacteriostatic dengan menghentikan perkembangan bakteri. Disaat konsentrasi nifurpirinol $10 \% \quad 1$ ppm dan vetstrep 2,5 ppm berhasil menekan perkembangan serta pertumbuhan bakteri $V$. alginolyticus maka bakteri Vibrio tersebut akan sama jumlahnya dan tidak bertambah. Dengan demikian sistem kekebalan tubuh induk kuda laut dapat mengatasinya langsung, dengan kata lain mekanisme kerja nifurpirinol dan vetstrep adalah dengan mengganggu sintesis protein $V$. alginolyticus. Antibiotik bacteriostatic berikatan dengan sub unit 16S-30S dan mencegah pengikatan aminoasil tRNA dari situs A pada ribosom, sehingga akan menghambat translasi protein.

Adapun cara kerja anti parasit copper sulfate, acriflavin dan formalin terhadap protozoa Ciliata, C. irritans dan Trichodina sp. adalah dengan menghambat sintesis protein pada ribosom, yaitu 30S dan 50S. Kedua komponen ini akan bersatu pada pangkal rantai mRNA menjadi ribosom 70S. Sintesis protein ini berlangsung pada ribosom dengan bantuan mRNA dan tRNA. Ada 2 proses yang terjadi dalam masuknya anti parasit ke dalam ribosom parasit, pertama disebut difusi pasif melalui kanal hidrofilik, kedua adalah sistim transport aktif. Anti parasit tersebut berikatan dengan ribosom 30S dan menghalangi masuknya tRNA-asam amino sehingga sintesa protein parasit akan terhenti dan kemudian mati. 
Pengendalian infeksi bakteri dan ektoparasit agak lebih mudah dilakukan dibandingkan infeksi internal. Treatmen untuk ektoparasit dapat dilakukan dengan metode perendaman, sedangkan untuk internal bisa dengan injeksi (intra muskular dan intra peritonial) atau secara oral melalui pakan. Roza et al. (1997); Roza dan Zafran (1998) melaporkan bahwa umumnya infeksi bakteri yang ditemukan merupakan infeksi sekunder. Metode yang aman, praktis, ekonomis dan efektif untuk mencegah dan mengontrol terjadinya infeksi penyakit adalah dengan mengkarantina dan mentreatmen induk yang baru datang dengan desinfektan serta menjaga kualitas air pemeliharaan yang baik, menghindari padat tebar yang berlebihan dan pemberian pakan yang bermutu baik. Jadi diharapkan dengan pengelolaan dan manajemen budidaya yang benar infeksi penyakit dapat dihindari, dengan mendiagnosa cepat dapat mengetahui agen penyebab penyakit sehingga dapat mencegah kematian massal yang berdampak kegagalan produksi, bahkan kerugian.

\section{KESIMPULAN}

Satu isolat bakteri $V$. alginolyticus dan 2 spesies protozoa Cilliata yaitu $C$. irritans dan Trichodina sp., ditemukan menginfeksi induk kuda laut. Bakteri $V$. alginolyticus yang berasal dari kuda laut tersebut tidak tumbuh secara in vitro dengan penambahan 1 ppm nifurpirinol $10 \%$ dan 2,5 ppm vetstrep. Serangan $C$. irritans dapat dikendalikan dengan perendaman kuda laut terinfeksi dalam larutan copper sulfat 0,5 ppm dan formalin 20 ppm, sedangkan Trichodina dapat dibasmi dengan perendaman kuda laut dalam larutan acriflavin netral $5 \mathrm{ppm}$ dan formalin $20 \mathrm{ppm}$ masing-masing selama 1 jam.

\section{UCAPAN TERIMA KASIH}

Terima kasih kepada Alm. Fris Johnny yang terlibat langsung dalam penelitian ini dan Bapak Edi Santoso yang telah memfasilitasi pengadaan sampel dan hewan uji, serta Slamet Haryanto yang telah membantu terlaksananya penelitian ini. Penelitian ini dibiayai oleh PT. Dilatur Prima.

\section{DAFTAR PUSTAKA}

Adiputra, Y.T., Triyanto, dan N. Probosunu. 2005. Identifikasi bakteri patogen pada kuda laut (Hippocampus kuda) di Balai Budidaya Laut Lampung. $J$. Fisheseries Science, 7(1):101-107.

Alcaide, E., C. Cill-Sanz, D. Esteve, C. Amaro, and L. Silvenia. 2001. Vibrio harveyi caused diseases in seahorse, Hippocampus kuda. J. of Fish Disease, 24(5):311-313.

Ari, W.K., Anindiastuti, A. Hafiz, dan Sudjiharno. 2005. Produksi massal kuda laut (Hippocampus kuda) dalam upaya mendukung ikan hias dan industri obat-obatan tradisional. Balai Budidaya Laut Lampung. Direktorat Jendral Perikanan Budidaya Kelautan Perikanan. Lampung. $13 \mathrm{hlm}$.

Asmanelli dan Ikhsan. 2000. Beberapa catatan mengenai kuda laut dan kemungkinan pengembangannya. Oseana, 18(4): 145-151.

Balcazar, J.L., A. Gallo-Bueno, M. Planas, and J. Pintado. 2010. Isolation of Vibrio alginolyticus and Vibrio splendidus from captive-bred seahorse with disease symptoms. Antonie van Leuweenhoek $J$. of Microbiol., 7(9):207-215.

Castrillo, A., D.W. Roberts, and J.D. Vandenberg. 2005. The fungal past, present and future : Germination, ramification and reproduction. $J$. of Invertebrate Pathology, 80: 46-56.

Cruz-Lacierda, E.R. 2001. Parasitic diseases and pests. In Health Management in Aquaculture, Lio-Poet al. (Eds.). Aquaculture Department, South-East 
Asia Fisheries Development Center, Tigbauan, Iloilo, Philippines. P.55-77.

Desrina, A. Taslihan, Ambariyanto dan S. Suryaningrum. 2006. Uji keganasan bakteri Vibrio pada ikan kerapu macan (Epinephelus fuscoguttatus). Ilmu Kelautan, 2(3):119-125.

Evelyn, T.P.T. 2002. Finfish immunology and its use in preventing infectious diseases in cultured finfish. In LavillaPitogo, C.R. and E.R. Cruz-Lacierda (Eds.) Diseases in Asian Aquaculture IV. 303-324 pp.

Faleiro, F., L. Narciso, and L. Vincente. 2008. Seahorse behavior and aquaculture: How to improve Hippocampus guttulatus husbandry and reproduction. Aquaculture, 282:33-40.

Hansen, C. and H. Cummins. 2002. Tropical marine ecology. http://www.pbs.org/ wgbh/nova/seahorse.htm.

Holt, J.G., N.R.Krieg, P.H.A. Sneath, J.T. Staley, and S.T. Williams. 2000. Bergey's manual of determinative bacteriology, $9^{\text {th }}$ ed . Maryland, USA. $787 \mathrm{p}$.

Johnny, F. dan D. Roza. 2014. Infeksi bakteri Vibrio alginolyticus pada lumbalumba hidung botol, Tursiops aduncus yang dipelihara di Lovina, Singaraja, Bali. Berita Biologi. J. Ilmu-ilmu Hayati, 13(3):297-302.

Koldewey, H.J. and K.M. Smith. 2010. A global review of seahorse aquaculture. Aquaculture, 302:121152.

Lin, Q., L. Junyi, G. Yongli, S. Li, C. Jin, and L. Junning. 2006. The effect of temperature on gonad, embryonic development and survival rate of juvenile seahorse. Aquaculture, 254:701-713.

Lin, Q., L. Junyi, and D. Zhang. 2008. Breeding and juvenile culture of the lined seahorse, Hippocampus erectus Perry 1810 from live to frozen food. Aquaculture, 277:287-292.
Lin, Q., L. Junyi, D. Zhang, and Y. Wang. 2009a. Weaning of juvenile seahorse, $H$. erectus Perry 1810 from live to frozen food. Aquaculture, 291:224229.

Lin, Q., L. Junyi, D. Zhang, and Y. Wang. 2009b. Effect of light intensity, stocking density, feeding frequency and salinity on the growth of subadult Hippocampus erectus Perry 1810. Aquaculture, 292:111-116.

Lom, J. 2005.Trichodinidae and other ciliates (phylum Ciliopgora) In Diseases and Disorders, 1:229-257.

Lourie, S.A., T.H. Haq, dan A. Tjakrawidjaja. 2001. Seahorses genus Hippocampus di Indonesia. Laporan Survey Lapangan. Bali. $72 \mathrm{hlm}$.

Mira, S. dan K. Yulianto. 2007. Durasi hidup Hippocampus kuda Bleeker 1852 pada percobaan pemeliharaan kuda laut secara indoor maupun outdoor. J. Oseanologi dan Limnologi, 33:281293.

Pawar, H.B., S.V. Sanaye, A. Muruqan, R.A. Sreepada, and Tanu. 2011. Effect of tank background colour on the growth and survival of juvenile yellow seahorse. H. kuda (Bleeker 1852) in the pelagic phase. The Israel J. of Aquaculture-Bamidgeh, 63(4):1-6.

Raj, S.T., A.P. Lipton, and G.S. Chanchan. 2010. Characterization and infectivity evaluation of Vibrio harveyi causing white patch disease among captive reared seahorse, Hippocampus kuda. Indian J. Marine Science, 39(1):151156.

Roza, D., Zafran, I. Taufik dan M.A. Girsang. 1997. Pengendalian Vibrio harveyi secara biologis pada larva udang windu (Penaeus monodon): Isolasi bakteri penghambat. J. Penel. Perikanan Indonesia, 4(2):13-23.

Roza, D. dan Zafran. 1998. Pengendalian Vibrio harveyi secara biologis pada larva udang windu (Penaeus monodon): 
Aplikasi bakteri penghambat. J. Penel. Perikanan Indonesia, 4(2):1-10.

Roza, D., F. Johnny, dan Yunus. 2001. Pengendalian vibriosis pada larva kepiting bakau melalui penggunaan bakterin. J. Penel. Perikanan Indonesia, 7(3): 28-32.

Roza, D., F. Johnny, dan Tridjoko. 2004. Peningkatan imunitas yuwana ikan kerapu bebek, Cromileptes altivelis terhadap infeksi Viral Nervous Necrosis (VNN) dengan cara vaksinasi melalui perendaman. $J$. Penel. Perikanan Indonesia, 10(1): 61-70.

Roza, D., F. Johnny, dan K.M. Setiawati. 2010. Infeksi parasit protozoa, Cryptocaryon irritans dan Scuticociliata pada induk ikan letter six, Parachanturus hephatus. 299$305 \mathrm{hlm}$.

Roza, D. 2011. Infeksi bakteri pada induk ikan clown, Amphiprion ocellaris. Buku Pengembangan Teknologi Budidaya Perikanan. 263-268 hlm.

Roza, D. 2017. Peningkatan imunitas benih ikan kerapu hibrid cantik dengan lipopolisakarida (LPS). J. Ilmu dan Teknologi Kelautan Tropis, 9 (1):161172.

Sadili, D. 2015. Pedoman identifikasi dan monitoring populasi kuda laut. Direktorat Konservasi Kawasan dan Jenis Ikan. Ditjen Kelautan, Pesisir dan Pulau-Pulau Kecil. Kementrian Kelautan dan Perikanan Jakarta. 43 hlm.

Sanaye, S.V., H.B. Pawar, A. Murugan, R.A. Sreepada, T. Singh and Z.A. Ansari. 2013. Diseases and parasites in cultured yellow seahorse, $H$. kuda (Bleeker 1852). Fish Chimes, 32(11): 65-67.
Shin, S.P., J.E. Han, D.K. Gomes, J.H. Kim, C.H. Choresca Jr, J.W. Jun and S.C. Park. 2011. Identification of Scuticociliate, Philasterides dicentrarchi from Indo-Pacific seahorse, Hippocampus kuda. African J. of Microbiology Res., 5(7):738741.

Syafiuddin, M. Zairin J.R., D. Jusadi, O. Charman, R. Affandi, D.D. Trijuno, dan Mutmainna. 2008. Pengaruh suhu terhadap perkembangan ovari kuda laut (Hippocampus barbouri) dalam wadah budidaya. Torani J. Ilmu Kelautan dan Perikanan, 18:81-86.

Vincent, A.C.J. and R.S. Clifton-Hadley. 2001. A case report. Parasitic infection of the seahorse $H$. erecfull. J. Wild Dis., 25:404-406.

Wooten, W. 2005. A guide to the most common seahorse diseases and medical conditions. Seahorse.org. $9 \mathrm{p}$.

Yanuhar, U. 2009. Mekanisme infeksi Vibrio pada reseptor ikan kerapu tikus Cromileptes altivelis. J. Ilmiah Perikanan dan Kelautan, 1(1):15-19.

Zafran, D. Roza, I. Koesharyani, F. Johnny and K. Yuasa. 1998. manual for fish diseases and diagnosis: marine fish and crustacean diseases in indonesia. Lolitkanta Gondol, Puslitbangkan, Balitbang Pertanian-JICA ATA-379. $44 \mathrm{p}$.

Zafran. 2016. Infeksi Cryptocaryon irritans pada benih kerapu hibrid cantik dan penanggulangannya. Indonesia. 1891943 pp.

$$
\begin{array}{ll}
\text { Diterima } & : 30 \text { Mei } 2018 \\
\text { Direview } & : 25 \text { Juni } 2018 \\
\text { Disetujui } & : \text { :05 Agustus } 2018
\end{array}
$$

